\title{
Symbiotic lymph node metastasis from breast cancer and melanoma
}

\author{
Jacob Juel, ${ }^{1}$ Frederik Harving, ${ }^{2}$ Manan Pareek ${ }^{3}$
}

${ }^{1}$ Department of Plastic Surgery, Aalborg University Hospital, Aalborg, Denmark ${ }^{2}$ Institute of Pathology, Aalborg University Hospital, Aalborg, Denmark

${ }^{3}$ Brigham and Women's Hospital, Heart and Vascular Center, Boston, Massachusetts, USA

\section{Correspondence to}

Dr Manan Pareek, mananpareek@dadlnet.dk

Accepted 25 July 2017
To cite: Juel J, Harving $F$ Pareek M. BMJ Case Rep Published Online First: [please include Day Month Year]. doi:10.1136/bcr-2017221430

\section{DESCRIPTION}

A 93-year-old woman with a history of stage 4 breast cancer and stage $\mathrm{T} 4 \mathrm{a}$ melanoma presented with pain in her left buttock and groin area. Her breast cancer type was invasive lobular carcinoma, 100\% oestrogen receptor positive with normal expression of human epidermal growth factor receptor 2. She had osteosclerotic vertebral metastases at the time of diagnosis and was treated medically with an aromatase inhibitor and an osteoclast inhibitor. Her melanoma had been of polypoid, nodular subtype with Breslow's thickness $6.8 \mathrm{~mm}$, no ulceration and 15 mitoses per $\mathrm{mm}^{2}$. The maximal diameter was $2 \mathrm{~cm}$, and it was resected surgically with a $0.5 \mathrm{~cm}$ margin.

At current presentation, focal relapse of melanoma of the buttock, with metastases to inguinal lymph nodes, was suspected. Local excision with a $0.5 \mathrm{~cm}$ margin and lymph node dissection were performed for diagnostic and palliative purposes (figure 1). Histological examination confirmed melanoma relapse located to the buttock, but the lymph node metastasis was of mixed origin (figure 2). Further examination revealed bicancerous primary metastasis of the same lymph node from melanoma and breast cancer, grouped in islets (figure 3). The metastases were seemingly growing symbiotically, as the breast cancer metastases was located centrally, while the melanoma metastases were lining the outer surface of all the islets. The findings were corroborated by immunohistochemical analyses, as the inner cells stained positive for oestrogen receptors and GATA binding protein 3 (both specific for breast cancer), whereas the outer cells stained positive for Sry-related HMg-Box gene 10 and S100 protein (both specific for tumours of neural crest origin). Three days postoperatively, the patient was discharged in good condition. Three years after presenting with relapse, she continues follow-up in the oncology outpatient clinic. She has

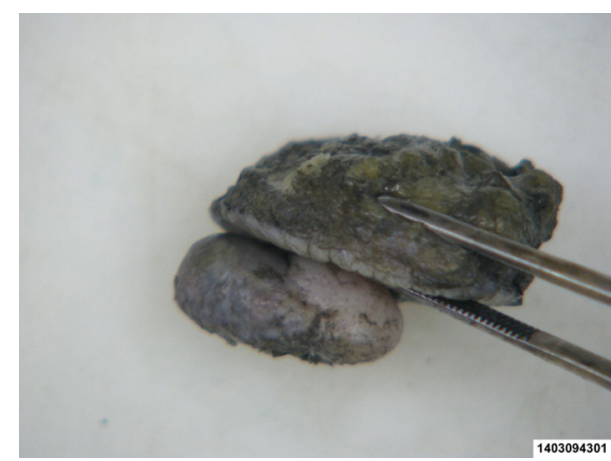

Figure 1 Excised melanoma of the buttock.

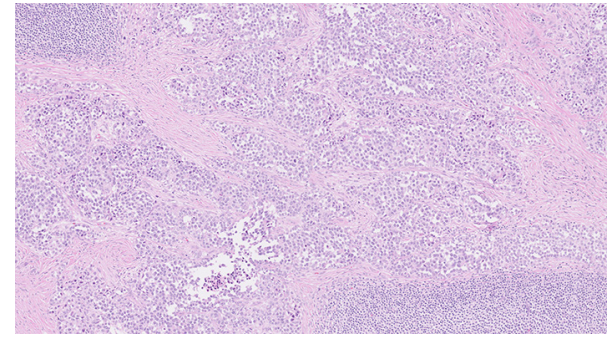

Figure 2 Mixed lymph node metastasis; H\&E stain.

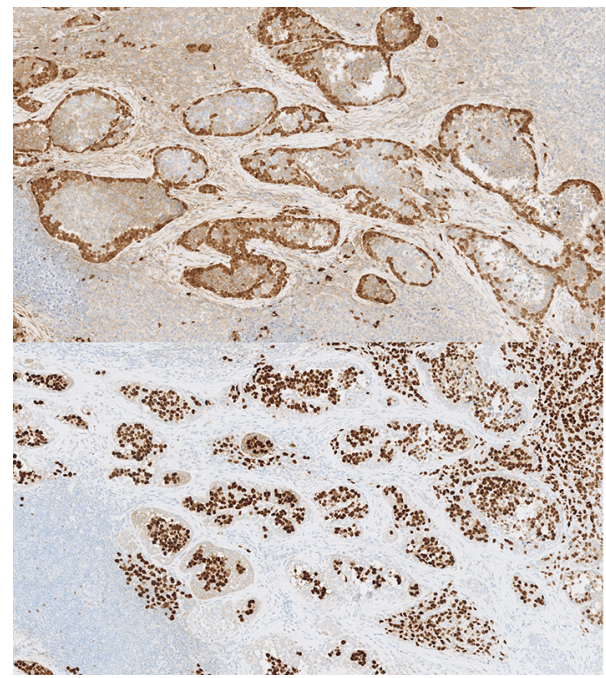

Figure 3 Upper panel: S100 immunostain; dark brown cells representing melanoma metastasis. Lower panel: oestrogen receptor stain; dark brown cells representing breast cancer metastasis grouped in islets.

wished to refrain from treatment other than palliative measures.

Breast cancer is the most common malignancy among women, while the incidence of melanoma is closely correlated to skin type, being highest among non-Hispanic Whites. ${ }^{1}$ Metastases, regional and distant, are a frequent and feared complication of both cancer types. ${ }^{2} 3$ The regional lymph nodes are commonly involved, with therapeutic and prognostic implications. In addition, the bone, liver and lungs are the classical sites for distant metastases in patients with breast cancer, ${ }^{2}$ whereas among patients with melanoma, locations include the skin, subcutaneous or lymph node sites, lungs and the central nervous system. ${ }^{3}$ To our knowledge, this is the first description of a single lymph node being subjected to bicancerous metastasis. The case illustrates that well treated synchronous cancers may progress concomitantly due to unknown mechanisms and 
thus highlights the importance of a careful pathological examination, including the usefulness of immunohistochemistry.

\section{Learning points}

- Breast cancer and melanoma are common malignancies among women.

- The regional lymph nodes are often involved in both cancer types.

- Well-treated synchronous cancers may progress concomitantly, rendering careful pathological examination particularly important for such patients.

Contributors JJ wrote the initial draft. All authors participated in collecting clinical data and interpretation of the findings, performing literature review, critical revision of the manuscript for important intellectual content and approval of the final version.
Competing interests None declared.

Patient consent Obtained.

Provenance and peer review Not commissioned; externally peer reviewed.

(c) BMJ Publishing Group Ltd (unless otherwise stated in the text of the article) 2017. All rights reserved. No commercial use is permitted unless otherwise expressly granted.

\section{REFERENCES}

1 U.S. Cancer Statistics Working Group. United States Cancer Statistics: 1999-2013 Incidence and Mortality Web-based Report. Atlanta: U.S. Department of Health and Human Services, Centers for Disease Control and Prevention and National Cancer Institute, 2016. https://nccd.cdc.gov/uscs/ (accessed 2 Apr 2017).

2 Senkus E, Kyriakides S, Ohno S, et al. Primary breast cancer: ESMO Clinical Practice Guidelines for diagnosis, treatment and follow-up. Ann Oncol 2015;26 (Suppl 5):v8-v30.

3 Dummer R, Hauschild A, Lindenblatt N, et al. . Cutaneous melanoma: ESMO Clinical Practice Guidelines for diagnosis, treatment and follow-up. Ann Oncol 2015;26(Suppl 5):v126-v132.

Copyright 2017 BMJ Publishing Group. All rights reserved. For permission to reuse any of this content visit

http://group.bmj.com/group/rights-licensing/permissions.

BMJ Case Report Fellows may re-use this article for personal use and teaching without any further permission.

Become a Fellow of BMJ Case Reports today and you can:

- Submit as many cases as you like

- Enjoy fast sympathetic peer review and rapid publication of accepted articles

- Access all the published articles

- Re-use any of the published material for personal use and teaching without further permission

For information on Institutional Fellowships contact consortiasales@bmjgroup.com

Visit casereports.bmj.com for more articles like this and to become a Fellow 